\title{
PILOMATRICOMA-STUDY OF 3 CASES AND REVIEW OF LITERATURE
}

\author{
S Maharjan ${ }^{1 *}$, M Tiwari $^{1}, \mathrm{~S}$ Ranabhat ${ }^{1}, \mathrm{R}$ Sherstha ${ }^{2}$ \\ ${ }^{1}$ Department of Pathology, Chitwan Medical College, Bharatpur, Chitwan, Nepal. \\ ${ }^{2}$ Department of Pathology, Nepalese Army Institute of Health Sciences, Kathmandu, Nepal. \\ *Correspondence to : Dr Sushna Maharjan, Department of Pathology, Chitwan Medical College, Bharatpur-10, Chitwan, Nepal. \\ Email: sushnamaharjan74@gmail.com
}

\begin{abstract}
Pilomatricoma is a benign neoplasm arising from hair follicle matrix cells. It is the most common lesion in pediatric age group. The most frequent sites are head and neck region followed by upper extremities. It is usually asymptomatic and present as a hard, subcutaneous slow-growing mass. Most of the cases present as a single nodule with a size smaller than $3 \mathrm{~cm}$ in diameter. We report three cases of pilomatricoma in arm and pre-auricular regions in a child and two young adults. We discuss the clinical presentation and histopathological findings of this uncommon skin tumor, and compare our findings with the previous literature.
\end{abstract}

Key Words: Benign, Follicle matrix cells, Neoplasm, Pilomatricoma.

\section{INTRODUCTION}

Pilomatricoma is a benign neoplasm arising from hair follicle matrix cells which was first described by Malherbe and Chenantais in 1880 as a benign, subcutaneous tumor and called calcifying epithelioma of Malherbe since then. ${ }^{1}$ It is also known as Pilomatricoma. Dubrewith and Cazenave described the characteristic histological features of the tumor with islands of epithelial cells, including shadow cells and giants cell in $1922 .{ }^{2}$ It is the most common lesion in pediatric age group ${ }^{3}$ with a slight predilection in males. ${ }^{3,4}$ The most frequent site is head and neck region followed by upper extremities, ${ }^{3,4,5}$ usually presenting as a hard, subcutaneous slow-growing mass. ${ }^{3,6}$

\section{Case Reports}

Case 1: A 9-year-old child presented with a nodular mass on the right pre-auricular region for 2 years. The lesion began to grow over the last few months. There was no history of pain and trauma. The mass was excised and sent for histopathological evaluation. On gross it was single, firm, measuring $2.5 \times 1.5 \times 1 \mathrm{~cm}$. Cut section was yellowish in color and firm.

Case 2: A 17-year-old female presented with a right preauricular cystic lesion for 4 years. Similarly, there was no history of pain and trauma. On examination, the lesion was cystic, soft, mobile and non-tender. The overlying skin was slightly bluish in appearance. Excision was done and sent for histopathological examination. Grossly, a single piece of tissue measures $3 \times 1.5 \times 1 \mathrm{~cm}$. Cut section contains gray-white cheesy material in the cyst.

Case 3: A 27-year-old female presented with a hard mass in the left arm for few years with mild tenderness. Excision was done and sent for histopathological examination. On gross examination, a single piece of hard mass measures $1 \times 1 \times 0.4 \mathrm{~cm}$.
Cut section shows gray-white, hard mass with calcification in the centre.

In all cases, histologically, lesions were located in dermis and sections show islands of cells composed of two types of cellsbasophilic cells and shadow cells. The basophilic cells are round to elongate with deeply basophilic nuclei and scant cytoplasm, arranged along the periphery of tumor islands. There is abrupt transition between basophilic cells and shadow cells. The shadow cells have distinct cell border with a central unstained area as a shadow of the lost nuclei. The stroma shows foreign body giant cell reaction adjacent to the shadow cells and keratin debris. Keratinization is present in two of the cases and calcification is seen in one case. In one of the cases, melanin pigment is also present in shadow cells and melanophages in the stroma.

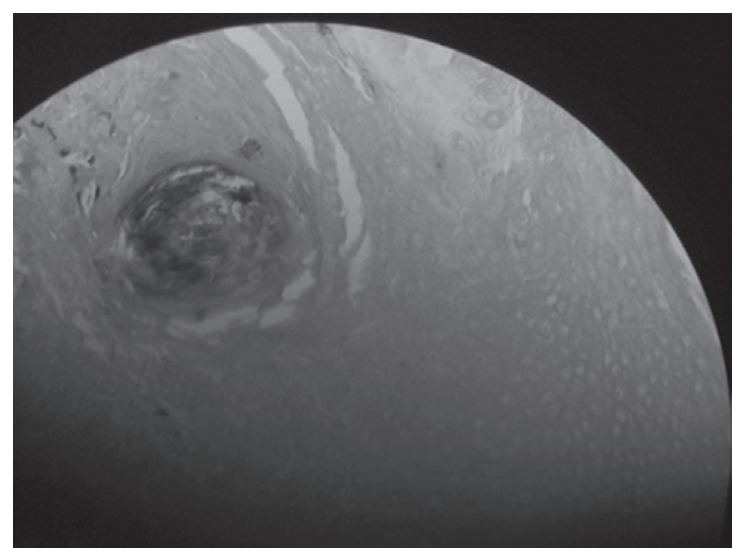

Figure 1: Microscopic photo of Pilomatricoma showing calcification and shadow cells. H\&E stain 


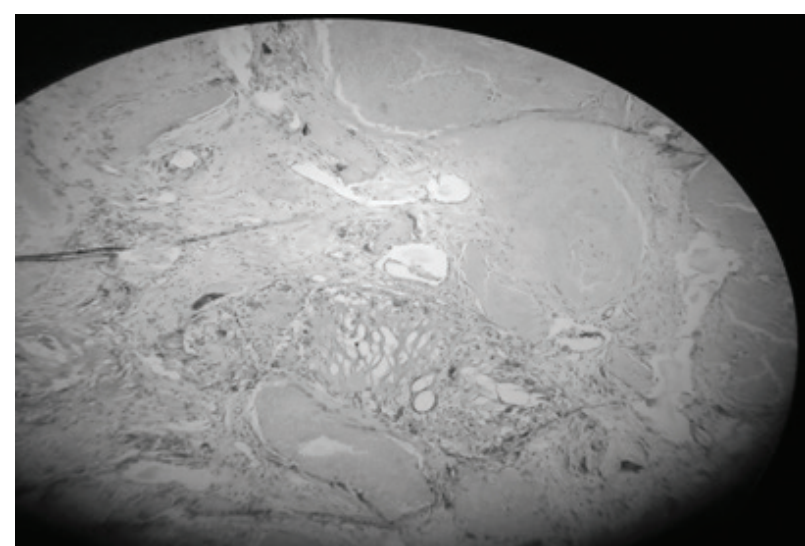

Figure 2: Microscopic photo of Pilomatricoma showing foreign body giant cell reaction adjacent to the keratin debris and melanophages in the stroma.H\&E stain

\section{DISCUSSION}

Pilomatricoma is a benign neoplasm that derives from hair follicle matrix cells. The most frequent site of these lesions are typically in head and neck region followed by upper extremities ${ }^{3,4,5}$ similar to the present study, with exception of cases in the trunk..$^{5,7}$ The age of presentation is usually in children and young adults, ${ }^{3,4,5}$ and they are commonly noted in females in small series of study of pilomatricoma, ${ }^{5,8,9}$ whereas slight male predilection was seen in large series of studies. ${ }^{3,4}$ Most of the lesions were $10-20 \mathrm{~mm}$ in diameter. ${ }^{3,4,5}$ However, the smallest lesion of $4 \mathrm{~mm}$ and the largest of $90 \mathrm{~mm}$ was also identified. ${ }^{5}$ Most of the cases present as a single nodule but multiple occurrences have also rarely been reported. ${ }^{3,4,7,8}$ Calcification has been frequently noted in $70 \%$ of cases and bone metaplasia in 1 case. ${ }^{5}$ Malignant transformation is also reported, though the clinical course is generally benign. ${ }^{6}$ Recurrence is rare after complete excision and most recurrences occur after incompletely excised tumors. ${ }^{6,8}$ There were 2 cases of recurrences out of 179 cases, ${ }^{4}$ and 1 case of recurrence out of 205 cases $^{3}$ have been reported.

Radiography may demonstrate foci of calcification but however, diagnostic imaging techniques are generally of little value for their evaluation. ${ }^{4}$ The findings of fine needle aspiration cytology can also be misleading as many cases of false positive diagnoses of pilomatricoma are made due to suboptimal sampling. ${ }^{10}$ Hence, histopathological examination is needed for definite diagnosis.

\section{CONCLUSION}

If young patients present with a complaint of a slowly growing, asymptomatic, small subcutaneous mass in head, neck and extremities, without a history of trauma or inflammation, a differential diagnosis of pilomatricoma should be considered. However, histological examination ultimatelyconfirms the diagnosis.

\section{REFERENCES}

1. Malherbe A, Chenantais J. Note sur 1' epitheliomacalcifie des glandes sebacees. Prog Med 1880;8:826-8.

2. Dubreuilh W, Cazenave E. De I' epitheliomacalcifie etude histologique. Ann Dermatol Syphilol 1922;3:257-68.

3. Guinot-Moya R, Valmaseda-Castellon E, Berini-Aytes L, Gay-Escoda C. Pilomatrixoma. Review of 205 cases. Med Oral Patol Oral Cir Bucal 2011 Jul 1;16(4):552-5.

4. Lan MY, Lan MC, Ho CY, Li WY, Lin CZ. Pilomatricoma of the head and neck: A retrospective review of 179 cases. Arch Otolaryngol Head Neck Surg 2003;129:1327-30.

5. Zaman S, Majeed S, Rehman F. Pilomatrixoma- Study on 27 Cases and Review of Literature Biomedica 2009;25(1):6972.

6. Pirouzmanesh A, Reinisch JF, Gonzalez-Gomez I, Smith EM, Meara JG. Pilomatrixoma: a review of 346 cases. Plast Reconstr Surg 2003;112:1784-9.

7. Chan JJ, Tey HL. Multiple pilomatricomas: case presentation and review of the literature. Dermatol Online J 2010 Apr 15;16(4):2.

8. Turhan-Haktanir N, Demir Y, Sahin O, Bükülmez A, Tüzüner M. Pilomatricoma: a review of six pediatric cases with nine lesions. Turk J Pediatr 2009 Jan-Feb;51(1):44-8.

9. Yencha MW. Head and Neck pilomatricoma in the pediatric age group: A retrospective study and literature review. Int $\mathrm{J}$ Pediatr Otorhinolaryngol 2001;57:123-8.

10. Seili-Bekafigo I, Jonjić N, Stemberger C, RajkovićMolek K.Additional cytomorphological criteria in diagnosis of pilomatricoma-benign tumor with bad reputation.Coll Antropol 2010 Mar;34(1):117-22. 